\title{
Effect of Employee Diversity on Firm Performance in Bangladesh
}

\author{
Homayara L. Ahmed ${ }^{1}$, Tanisha Bukth ${ }^{2}$ \\ ${ }^{1}$ Assistant Professor, Institute of Business Administration, University of Dhaka, Bangladesh \\ ${ }^{2}$ Lecturer, Institute of Business Administration, University of Dhaka, Bangladesh \\ Email: homayara@iba-du.edu; tanisha@iba-du.edu
}

\begin{abstract}
In the changing world, diversity in workplace is the new reality not just for complying with equal employment opportunity but also for catering to their diverse customer base. There are theories that have spoken both for and against the proliferation of diversity. Theories such as Ashby's Principle of Requisite Variety and Information / Decision-making Perspective suggest that certain diversity attributes heighten the benefit of heterogeneity in organizations that in effect, ameliorate the quality of decision-making. Moreover, many previous studies have shown that workplace diversity indeed affects firm performance positively. The current research has studied the relationship of core diversity factors (such as gender, religion and race) that are relevant in the context of Bangladesh with organizational performance; and the study was conducted with both primary and secondary data from 80 listed firms in the Dhaka Stock Exchange. Research findings show that there is a significant positive relationship between organization-wide gender diversity and firm performance.
\end{abstract}

Keywords: Employee diversity, gender diversity, firm performance, Bangladesh.

\section{Introduction}

\subsection{Background of the Study}

The 'diversity wave' began impacting organizations a few decades back as cultural and legal implications of managing diversity within organizations had started gaining in prominence. In recent times, however, diversity management has become a strategic area of action within organizations as globalization and change in demographic workforce composition propelled an increase in representation of minorities, as a result of actions that went beyond legal or moral requirements.

Ely \& Thomas (2001) offered a seminal contribution by way of explanation of what constitutes 'beyond' legal and moral requirements through the identification of three managerial perspectives on diversity: i.e. the reasons why diversity is perhaps actively sought in organizations. According to these authors, diversity in organizations might help avoid discrimination and address fairness, promote access and legitimacy to people, and integrate diverse know-how and learning. As a result, pro-diversity management firms promote business diversity as it would likely offer better information - through the understanding of different ethnicities / race or other background of people who might have had a different set of experiences and views of the world.

Throughout time and across researches, diversity has been defined in multifarious ways. And for quite a long time, diversity had been defined only in terms of demographic variables: gender, race and ethnicity, tenure, education, functional background, marital status etc. These are basically the surface level or observable trait diversity that represent approximately $89 \%$ of researches as estimated by Jackson, Joshi, \& Erhardt (2003). Such surface traits are somewhat easy to use in research and many times, have been used as proxies for the underlying deeper traits. Other non-demographic diversity variables include values, attitudes, conscientiousness, affect, network ties, pay, individual performance etc. (Jonsen, Maznevski, \& Schneider, 2011)

A more relevant working definition of diversity states that workforce diversity refers to the "composition of work units (work group, organization, occupation, establishment or firm) in terms of 
cultural or demographic factors that are salient and symbolically meaningful in the relationships among group members" (DiTomaso, Post, \& Parks-Yancy, 2007, pg. 474).

Mor Barak (2005, pg. 132) offered a global definition of diversity as:

"Workforce diversity refers to the division of the workforce into distinct categories that (a) have a perceived commonality within a given cultural or national context and that (b) impact potentially harmful or beneficial employment outcomes such as job opportunities, treatment in the workplace, and promotion prospects - irrespective of job-related skills and qualifications." (cited in Jonsen et al., 2011).

Armed with the basic understanding of the concept of diversity, the pertinent understanding with regards to this study is - irrespective of the extent of workforce diversity present within organizations (and, whether it is deliberate or not), it is nevertheless a stark reality to be dealt with!

Many studies have shown how diversity impacts firm performance. A survey of companies from Fortune 500 by Catalyst (2001) showed that the top quartile firms in terms of female representation in the boards had higher return on invested capital over the period 2004-2008 in comparison to the bottom quartile of firms in terms of board female representation (Low, Roberts, \& Whiting, 2015).

Such top management diversity is itself a prominent indicator of how the respective management promotes workforce diversity within their organizations (McMahon, 2010). Their belief is that more diversity would increase performance effectiveness; a view that is becoming more popular as organizations are facing challenges with talent recruitment in the wake of a more diverse active employment market and a similarly diverse customer base.

However, there has been mixed results from multifarious studies on gender diversity and organizational performance: not only some studies found both positive effect (in accordance with resource-based view) and negative effect (as explained by social identity theory), but also, other studies found a non-linear relationship with a critical mass requirement for gender ratio to really make an impact on decision-making in an organization (Homberg \& Bui, 2013).

Although the focus of majority of studies has been on workforce diversity improving firm performance or on diversity management as a signal for greater diversity concern to enhance firm reputation etc., the concern for diversity management as an area of study is perhaps rooted in much deeper social concerns. It has been seen that more women than men are participating in the workforce now and it is not just happening in the "invisible economy" only that encompasses caregiving and domestic work etc.

Work-life balance is another branch of diversity-firm performance research. It is not just about the imbalance of gender participation in workforce, there is implication on work-life balance (WLB) for both genders. As childcare responsibility is being shared between both working parents, data suggests that men are likely to experience similar work-life challenge as women do (Duxbury and Higgins, 2008, cited in Panisoara \& Serban, 2013). Research findings have shown parental responsibilities are linked to employee work-life conflict as parents have more demand and less control over their time; hence, resulting in work-related effects such as job dissatisfaction, absenteeism, intention to quit, stress etc. (Panisoara \& Serban, 2013). These in turn affect workplace productivity.

It is not only in the area of gender diversity where employers are showing concern; according to Ely and Thomas (2001), labour market research provides further evidence that employers are putting more emphasis on increasing ethnic workforce diversity to be more compliant with equal opportunity requirement; to address labour and specific skills shortage and to reduce labour cost.

\subsection{Problem Statement}

As the background precludes, workforce diversity is a reality that organizations all over the world are taking in stride. Many studies done in this area have shown that there is a relationship between employee diversity (mostly in terms of gender, race, religion etc.) and firm performance; studies have also shown how organizations are pre-emptively seeking such diversity in the top management (mostly seen in studies relating to board diversity) to harness the power of diversity perspective in business decision-making. Moreover, organizational diversity consciousness is also not just for the purpose of enhancing better decision quality for improving firm performance, employee diversity is becoming a necessity - a reality, with increasing labour-market orientation by the organizations as they strive to create a diversity balance in line with demographic changes. 
In Bangladesh, where the national employment data presents a mismatch with demographic representation in different organizations, these firms need to take a relook at their level of productivity and overall performance as they gear toward faring a far competitive market than before.

According to data published by the Bangladesh Bureau of Statistics, as per data of 2015, the male to female ratio of population consolidated across three age groups (from age 15 to $60+$ ) is $41.35 \%$ male to $58.65 \%$ female. The same population in the labour force however, is $69.3 \%$ male to $30.7 \%$ female (with urban employed population being $71.8 \%$ male to $28.2 \%$ female) (Alam et al., 2015). The decrease in the female participation in employment is because of lack of auxiliary support for home management and family welfare (Rashid, 2018).

According to the latest census of 2011, Sunni Muslims make up 90\% of the population of Bangladesh followed by $9.5 \%$ of Hindus. Christian population makes up for the majority of the remaining $0.5 \%$ with Budhhist, Shia, Ahmadi and agnostic population - all of the latter constitute a few thousand in number only. The ethnic minorities practice minority religions and many are also converted Christian, live mostly in the Chittagong Hill Tracts (CHT) and the northern districts. (US Department of State, 2016).

It is to be seen through the study that the core diversity factors that include gender, race, physical disability etc. are not well represented in the organizations in Bangladesh.

Although the findings of many researches have shown that there is a contrast in findings as to the relationship between diversity and firm performance, which was further proclaimed in meta-analytic studies by Bowers et al. (2000) and Webber \& Donahue (2001), Joshi \& Roh (2009) had suggested that there are country based contextual factors that could generate a certain type of relationship between diversity and firm performance.

Moreover, a majority of such studies have also been done mainly in the US context and only recently, similar studies have been conducted in Asia.

In Bangladesh, no such study has been carried out to understand the employment pattern of workforce diversity nor to identify whether any form of such workforce diversity has a relationship with firm performance.

The problem statement of the research is thus being framed as:

Does workplace diversity (covering gender diversity, racial diversity and diversity through religion) affect firm performance?

\subsection{Research Questions \& Research Objectives}

\section{Research Objective}

To determine whether employee diversity factors affect firm performance positively.

The study looks into specific core diversity factors such as gender, race and religion within the employment scenario in Bangladesh that can affect firm performance.

The research questions are thus framed as follows:

$>$ Does gender diversity in the workforce affect firm's financial performance?

$>$ Does religion-based diversity in the workforce affect firm's financial performance?

$>$ Does racial diversity in the workplace affect firm's financial performance?

Other core diversity factors, such as age, marital status, sexual orientation and physical disability, chosen from the list of diversity factors that have been termed as grounds for discrimination, have not been included in the study on account of possible unavailability of data (for instance, for sexual orientation is a social taboo in the context of Bangladesh, there is severe lack of supportive / grooming environment for the physically challenged people etc.).

This being one of the first studies on workforce diversity vs. firm performance in Bangladesh, the diversity factors were chosen firstly, to see a reflection of the nature of organizational workforce diversity vis à vis the demographic pattern within the country; and secondly, to assess whether such factors (not at the board level, but on an organizational scale) have a relationship with organizational performance.

On account of the nature of the study that covers core diversity factors holistically across the organizations, the organizational performance parameter chosen in the study has not been Return on Asset (ROA) or Return on Equity (ROE) but rather Operating Profit Margin (OPM), which relates to an internal organizational performance factor, i.e. the operating profit that is essentially the collective effort of the total human capital within the organization. 


\subsection{Significance of the Study}

Bangladesh is riding through a time of great change with its youth population making up the demographic majority. Besides, the country is poised to enter into the middle-income group with economic performance showing GDP growth of $7.28 \%$ in 2017, with a growth of above $13 \%$ in manufacturing sector, and $6.33 \%$ in service sector that makes up for $52.85 \%$ of GDP. Such growth pattern suggests growth in employment and a need for higher participation of qualified and skilled human resources from all walks of life.

However, the majority of organizations within the country still have a paternalistic mindset / culture that carries forward employment trend of decades ago, from a bygone era when a single-earning member from each family coming from a largely Muslim-based population would be in the employment market. Notions of diversity were not sought, encouraged nor included in policies or strategies.

In order to meet the challenges of the coming period, organizations now need to proactively seek diversity in multiple forms that would help create an employee base that can reflect the thoughts, lifestyle, expectations of the very same customer based these organizations are catering to. As literature shows, past studies have predicted more creativity and innovation and better decision quality with greater diversity in organizations. As such, these firms need to have diversity inclusive policy and strategy in order to create a workplace that fosters their satisfaction and productivity.

This study is a first of many to promote the 'diversity-cause' as a way of incentivizing organizations by showing a relationship between diversity factor(s) with organizational performance.

\section{Literature Review}

Throughout diversity vs. organizational performance literature, a number of theoretical frameworks have been used to formulate such studies.

The Signaling theory was used in the study to investigate the relationship between board diversity (on account of race and gender) and firm performance through the mediating role of firm reputation and innovation (Miller and del Carmen, 2009 cited in McMahon, 2010). The same theory was also used in the study to investigate the relationship between diversity through sexual orientation (LGBT) and firm performance (Johnston \& Malina, 2008). According to the authors, their research findings show that LGBT friendly workplace policies do not negatively affect firm reputation; i.e. the relationship at its worst is 'value-neutral'. Their premise based on the signaling theory was LGBT work equality would suggest good corporate citizenship that would likely increase firm value; although the opponent view was that of public backlash on account of lower social acceptance of LGBT lifestyle. Moreover, the authors later felt that the study was conducted at a time when LGBT rights were still being questioned socially as can be seen by the findings at GALLUP poll which showed that $40 \%$ of polled people felt LGBT orientation was not an accepted 'alternative lifestyle' (Johnston \& Malina, 2008; Saad, 2008)

Using the knowledge-based view of the firm, it was argued that a wider array of employee background would likely provide a broader 'field of vision'. Studies using this perspective highlighted the significant challenge posed by the social categorization phenomenon where groupthink prevails, and as such, used the theoretical insight from knowledge and legitimacy perspectives to promote that diversity is no longer to be viewed as unidimensional; its heterogeneity in effect, encompasses employees' functional background, work tenure, network ties etc. that go beyond demographic factors. Moreover, such heterogeneity recognizes the presence of an overlap of these different 'diversity criteria' resulting in, what is termed as, 'faultlines' (McMahon, 2010).

Perhaps presence of faultlines is one reason why there is such a drift between studies related to workforce diversity and firm performance. There are studies with findings from both sides: showing a significantly strong positive correlation and also a significant negative correlation. Most of these studies were US-based and also covered workforce diversity at its most rudimentary level (gender, ethnicity, race etc.). Such studies have shown that while there is an increase in the number of female board members, board gender diversity does not significantly impact firm's financial performance (Wang and Clift, 2009; Marimuthu and Kolan Daisamy, 2009); other studies revealed a positive relationship with the presence of minorities / women in boards vs. firm performance (Carter et al., 2003; Erhardt et al., 2003; Campbell and Minguez-Vera, 2008 cited in Low et al., 2015); still others have shown that presence 
of women in boards rather had a negative impact on ROA and Tobin's Q in Indonesian firms (Darmadi, 2011; Low et al., 2015).

Different meta-analyses have found no overall relationship between diversity and performance (Bowers et al., 2000; Webber \& Donahue, 2001) or rather, found a very small negative effect (Jonsen et al., 2011; Stewart, 2006).

According to Joshi \& Roh, (2009), the reasons for such inconsistent findings may be due to contextual factors, which may be explained in the form of organization climate, country location, task-orientation, team-orientation etc. They even found occupation and industry level moderators that explained the variation in effect size of the relationship (Jonsen et al., 2011; Joshi \& Roh, 2009). Moreover, there is a presence of publication bias in this area (Homberg \& Bui, 2013).

Also, the results used in the meta-analysis represented much work in single-nation setting and a lot of such studies inculcated US-oriented research agenda; hence, while racial diversity would be relevant in US based research, caste / religious diversity would be more relevant in India. In their paper, Jonsen et al. (2011) presented a number of lively examples to explain the country-driven context of diversity: for instance, while culturally, German companies legitimizes diversity through a link to firm performance, Nordic or Danish countries promote value-based homogeneity which corresponds to equality and thereby, promoting diversity contradicts their sense of equality.

In the Asian context, in countries such as Hong Kong, South Korea, Malaysia and Singapore, similar studies relating diversity to firm performance have yielded results that account for cultural variation. While many studies have shown that an increasing number of female directors on board have positive effect firm performance as measured by ROE, such positive effects surprisingly seem lower in countries that have seen higher empowerment and participation of women in their economy (Low et al., 2015). Based on qualitative findings from such studies, researchers coined the term 'tokenism', which means 'a perfunctory gesture of inclusiveness of minority groups'(Kanter, 1977 cited in Gröschl \& Arcot, 2014; Low et al., 2015). It was their finding that such tokenism has rather impeded firm performance and this tends to happen in countries that harbor forced appointment of female directors on board or have mandatory gender quota to account for higher gender diversity.

The theory of tokenism underpins the concept of 'critical mass'; a concept that explains the need for an optimal number (a ratio) that puts the female voice in a position to be heard - anything less, the minority group would not be strong enough to push their agenda; any point above, the group would fail to harness a unified voice. The optimal point representing the critical mass is the reason why some studies have found a non-linear relationship between gender diversity and firm performance.

In their study, Low, Roberts and Whiting (2015) found that gender diverse boards have a positive effect on firm performance. However, the effect is moderated by the country's attitude towards women at work; their findings revealed that there is a positive relationship between board gender diversity and firm performance in countries where there is a supportive attitude towards women empowerment. However, interestingly, it was also identified that the relationship is further enhanced in countries where socially, women participation at work and empowerment are rather constrained. The authors termed this as cultural resistance and suggested that this was more prevalent in the Asian cultures where tokenism is present in companies which are moreover trying to conform to the western ideology of gender equality.

In a study between racial diversity and firm performance, it was found that there is indeed a relationship between the two with the mediating role of 'competitive intensity' and the moderating role of 'environmental munificence' (Andrevski, Richard, Shaw, \& Ferrier, 2014). Here, competitive intensity defines the speed vs. cost of developing new competitive actions whereas environmental munificence refers to the high growth potential of the firm in an industry.

In 2016, researchers Ali and Azmi undertook a study to investigate the role of religion as a diversity factor affecting the performance of Islamic banks. Not many studies had been carried out before that in relating religion diversity and firm performance, which was perhaps because the objective of a firm in maximizing shareholder value is an acceptable value in all religions and thereby making religion-based diversity an irrelevant context. Also, corporations did not base their operations on the principles of certain faiths. However, in countering the latter perspective, with the growth of Islamic finance companies - where firms specifically state in their mission that they offer products and services in accordance with Islamic shariah principles, the presence of Muslims in decision-making roles perhaps become relevant. The study was thus undertaken to investigate the relationship between religion 
diversity in boards and firm performance and their findings showed that the relationship between religion diversity (in boards) and firm performance was not significant (Ali \& Azmi, 2016).

The financial performance parameters used in all these studies were mostly Return on Assets (ROA), Return on Equity (ROE) in the short-run (Wang and Clift, 2009; Marimuthu and Kolan Daisamy, 2009) and Tobin's Q in the long run (Carter et al., 2003; Darmadi, 2011). Moreover, most studies have used only financial performance to estimate performance outcome of firms; whereas other metrics such as quality of results, social integration, quality of decision-making etc. could also have been used as performance parameter that go beyond financial measures (McMahon, 2010).

Various literature on workforce diversity show that gender, religion, race (as core diversity factors) have been used mostly in assessing whether such factors affect firm performance (measured in financial parameters). Studies in the later period have focused on such diversity factors at the board level. Also, while most studies were done in US and other western context, few studies in recent years have been conducted in the southeast Asia where cultural and contextual factors have arisen as parameters that too affect the diversity-performance relationship.

\section{Research Framework}

\subsection{Theoretical Background}

This study uses the Information / Decision-Making perspective that underlines the positive impact of diversity on decision-making. According to this perspective, the quality of decision is determined based on the level of information exchange within a team and how the team processes this information; hence, high level of diversity would likely lead to better / wider perspectives with a greater amount of information being shared resulting in enhanced decision quality (Kreitner and Kinicki, 2007).

The theory is in line with Ashby's principle of requisite variety (1956) which suggests that certain diversity attributes, such as functional background, network etc. may enrich individuals' supply of ideas and approach to knowledge that in essence, foster the benefit of heterogeneity in organizations (McMahon, 2010).

Moreover, according to Pfeffer and Salancik's (1978) resource dependence theory, the purpose of accumulating critical resources is to drive organizational strategies. In their conceptualization model that provided a theoretical backing for integrating diversity (particularly, ethnicity in their case) as a business strategy, Ortlieb \& Sieben (2013) suggested that organizations pursue diversity strategy as a way of adding value through simply labour input, background, anti-discrimination etc. and each strategy is a response to the environmental challenges. Extending this diversity-business strategy relationship, a similar finding suggests that diversity, as a result of enhanced decision-making, higher creativity, innovation, competitive advantage etc. affects performance (Gupta, 2013). However, the study further included qualitative factors such as managerial accountability, efficient communication, team-orientation etc. as mediators between the diversity-performance relationships.

On the backdrop of such theoretical perspectives that - heterogeneity brings forth a greater body of knowledge and wider perspective that procures better decision making (as organizations consciously choose workforce diversity as a business strategy), Behaviour Theory of the firm (Cyert and March, 1963) on the other hand, posits that homogeneity hampers innovation as studies have shown social conformity leads to groupthink (Low et al., 2015).

Under such assumptions, this study was designed to understand the relationship between workplace diversity with organizational performance in the context of a growing economy like Bangladesh.

\subsection{Hypotheses}

\section{Research Objective}

To determine whether employee diversity factors (gender, religion, race) affect firm performance (Operating Profit Margin or OPM) positively.

H1: Gender diversity affects firm performance positively.

H2: Racial diversity affects firm performance positively.

H3: Religion diversity affects firm performance positively. 


\section{Methodology}

The research philosophy falls under critical relativism and it is a deductive study as the data relating the two constructs: firm performance and employee diversity, are observable and measurable and the relationship as well, has been widely tested in various past researches. There is a clear theoretical perspective linking diversity with organizational performance.

\subsection{Research Design}

The design of the study is explanatory in nature. It follows a full-fledged survey design method using questionnaire as the data collection tool for the collection of primary data at organizational level. Some secondary data on the financial information of the organizations for the same year were also collected from the respective company websites.

\subsection{Sampling Plan}

The population of the study constituted of all organizations registered with the Dhaka Stock Exchange, Bangladesh. The population (of enlisted companies), as such, was chosen for the veracity of the financial accounts presented by the organizations when registered with the stock exchange. Besides, the organizations are of certain size (as the SMEs were left out from the pool) and have a certain level of professionalism to have passed the due diligence needed to be enlisted in the capital market.

Data from 80 organizations from a list of 308 listed companies were collected. The companies spanned multiple industries such as telecommunications, pharmaceuticals, ready-made garments, power, engineering, food \& allied, financial institutions, cement and IT sectors.

\subsection{Instrumentation and Data Collection}

All data collected were at organizational level. These were cross-sectional data for companies listed in the Dhaka Stock Exchange with financial data collected from the annual statements for the period ended June 2016. A questionnaire was used to collect data on age, gender, nationality, ethnicity, religion, marital status, parental status. These data were collected covering only the management positions of the organizations in the sample; the labour workforce (non-exempt employees) was not included in the data.

Lastly, the primary data i.e. data on the employees were collected directly from the organizations from the representative from their HR department. Secondary data on the financial information of the organizations were collected from the website of Dhaka Stock Exchange and the uploaded annual reports of all the listed organizations in the digital repository of IDLC Finance company Ltd.

\subsection{Data Analysis}

Regression Analysis using SPSS 12 was run on the data with financial performance of organizations as the dependent variable and the ratio of each diversity factor as each independent variable.

$>$ Operating Profit Margin (OPM)

OPM is the dependent variable of the model and is defined as the operating profit of the firm for the year ended in June 2016 divided by total annual revenue for the same period. The OPM helps to standardize the variable by taking into consideration the different sizes of the organizations in terms of their total revenue.

$>$ Gender diversity Gender diversity has been used as a ratio of total female employees to total male employees in the managerial position of the organization.

$>$ Religion based diversity Religion based diversity has been used as a ratio of total non-muslim employees to total number of muslim employees in the organization.

$>$ Racial diversity Racial diversity has been calculated as the ratio of total number of foreign employees and ethnic population to the non-ethnic local population as managerial employees in the organization. 


\subsection{Implications and Limitations}

The study was singularly focused on the diversity relationship with firm performance and hence, there were likely other independent variables missing in the regression model. Secondly, the diversity data were collected as a consolidated whole for each organization rather than in consideration for functional variability or for top management team or board; the hierarchical segregation of data possibly could also have had an impact on the relationship.

Lastly, the most significant limitation of the study is the specification of the model had considered only diversity factors with relations to firm performance. The model has not taken into consideration other independent variables, specially related to firm size, industry, competition etc.

\section{Discussion of Findings}

Descriptive findings of the study show that the data collected from the 80 organizations in this study has an average of $82 \%$ male vs. an average of $16 \%$ of female representation in the organizations with 4 companies having no female employee in their payroll at all. Diversity through religion show an average of $82 \%$ of Muslims with the rest $18 \%$ being covered by other religions, which actually shows a better managed diversity scenario as the current Muslim population in the country is about $90 \%$. Ethnic representation, on the other hand, is merely $1.4 \%$ on an average in the studied organizations and employment of physically-challenged people has been seen in only 6 organizations out of the 80 studied, with a maximum number of 8 people (i.e. merely a $3 \%$ of the population of that particular organization).

A standard multiple regression was run with Operating Profit Margin (OPM) as the dependent variable (DV) and gender ratio, racial diversity ratio and religion diversity ratio as the three diversity factors used as independent variables (IV). The results indicate how well this set of variables (the diversity ratios) are able to predict firm performance through OPM. All data tables from SPSS are presented in Appendix A.

Table 1. Correlations Matrix

\begin{tabular}{llcccc}
\hline & & OPM & Gender Ratio & Racial Ratio & Religion Ratio \\
\hline \multirow{3}{*}{ Pearson } & OPM & 1.000 & .436 & -.093 & -.044 \\
Correlation & Gender Ratio & .436 & 1.000 & -.011 & .274 \\
& Racial Ratio & -.093 & -.011 & 1.000 & .019 \\
& Religion Ratio & -.044 & .274 & .019 & 1.000 \\
\hline \multirow{5}{*}{ Sig. (1-tailed) } & OPM &. & .000 & .209 & .351 \\
& Gender Ratio & .000 &. & .462 & .008 \\
& Racial Ratio & .209 & .462 &. & .437 \\
\hline
\end{tabular}

As can be seen from Table 1, the independent variable, Gender Diversity ratio correlates substantially with Operating Profit Margin (OPM) with the correlation coefficient between the two variables being 0.436 which is above the acceptable coefficient point of 0.3 (Tabachnick and Fidell, 2013). The other independent variables are also not correlated with one another, with all data being less than 0.3. Moreover, from Table A2 in Appendix A, it can be seen that VIF for all the independent variables are less than 10, indicating there is possibly no case of multicollinearity.

The Scatterplot of the standardized residuals show that the residuals are roughly rectangularly distributed, with most scores concentrated in the centre. There is no clear or systematic pattern to the residuals. However, there are two outlier cases (which are more than 3.3 or less than -3.3 in the scatterplot; Tabachnick and Fidell, 2013). 


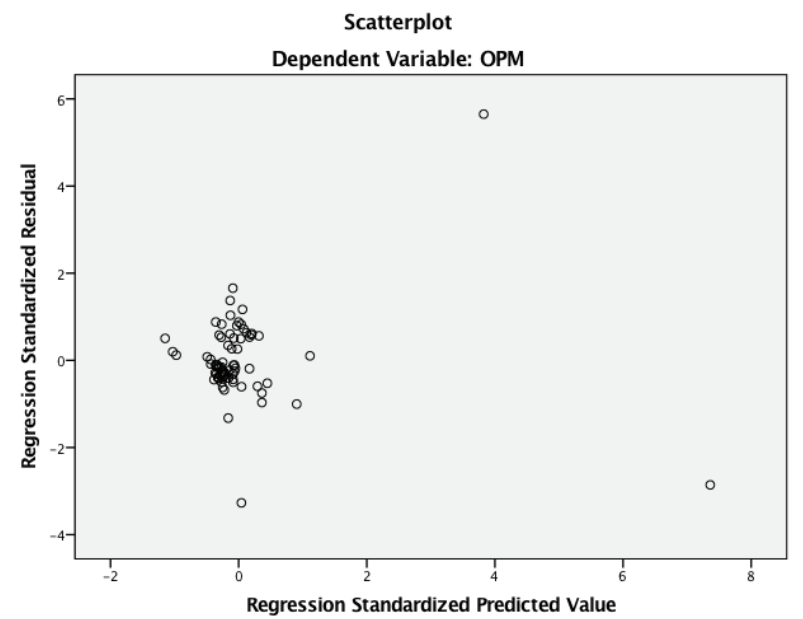

From the Model Summary box, it can be seen that the $\mathrm{R}$ square of the model is 0.226 , which basically shows how much of the variance in the dependent variable (OPM) can be explained by the model.

$$
\begin{gathered}
O P M=0.204+0.323 * \text { Gender Diversity Ratio }-1.431 * \text { Racial Diversity Ratio }-0.047 \\
* \text { Religion Diversity Ratio }
\end{gathered}
$$

Of the three independent variables, the standardized Beta coefficient of Gender Diversity Ratio is the largest (at 0.483) compared to the other two independent variables (which are -0.084 and -0.175 ). The Coefficient table (in Appendix A) also shows that Gender Diversity Ratio is the only independent variable that has p-value less than 0.05 . The same table also shows that the part correlation coefficient for Gender Diversity Ratio is 0.464 , which when squared gives the figure 0.215 ; in other words, it shows how much of the total variance in the dependent variable is uniquely explained by Gender Diversity Ratio and how much R-square would drop if this independent variable were taken out of the model. As can be seen, as this particular IV - Gender Diversity Ratio is the only significant variable in this model, the partial correlation R-square, which is $21.5 \%$ is very close to the model R-square of $22.6 \%$.

The results of the analyses presented above help us to answer the question whether workplace diversity factors affect firm performance: our model explains $22.6 \%$ of the variance in OPM and Gender Diversity Ratio is the only significant variable of the three that affects OPM (as per this model).

\section{Conclusion}

The study on workplace diversity impacting firm performance is quite a novel study in the perspective of Bangladesh. Most work have focused on gender or age or ethnicity as diversity factors that impact individual performance; for instance, how job satisfaction increases with age of employees (Kundu, 2016) or how gender diversity is impacted in countries such as Bangladesh because of a lacking in organizational support system (Rashid, 2018) etc. And other studies focused on diversity inclusion in organizations and inequitable HR practices (through recruitment, appraisal, salary, promotion etc.) or presence of glass ceiling (Ahmed, Alam, \& Anam, 2010).

This study has focused on the impact of workplace diversity on firm performance, taken on a holistic scale for the whole organization, rather than at top management or board level. As the study was built upon the concept of diversity bringing in requisite background to enhance quality of decision-making, the performance of the firms was considered in terms of Operating Profit Margin, which is far likely to be impacted by the quality of interaction and decision-making at all levels of organization (while working at the operational level).

The findings show promising result for gender diversity (over other core diversity factors) as having an effect on firm performance. As a complementary effort with other researches on diversity inclusion in firm or organizations' role in diversity management through better HR practices etc., this study as an onset, shows the importance of consciously introducing diversity in work environment as a means to increase organizational performance. 
However, there is still a wide scope of research to be covered in this area: particularly in the context of Bangladesh. As has been mentioned in the literature before, diversity researches are moving into context-based studies that cover culture, nations etc. The concept of diversity itself is being defined in terms going beyond the core demographic factors. Lastly, newer researches are measuring firm performance not only in terms of financial factors but also in terms of qualitative measures such as quality of results, social integration etc.

\section{References}

1. Ahmed, H. L., Alam, M. J., \& Anam, R. (2010). Factors Affecting Glass Ceiling Situation of Women Working in Management Positions in Bangladesh Context. Journal of Business Administration, 36(1 \& 2), 1-24.

2. Alam, M., Roy, D., Alam, S., Ashrafuzzaman, M., Ahmed Miah, M., Alam, K., ... Abdullah, M. (2015). Age-sex Composition of Bangladesh Population. Population Monograph of Bangladesh. Dhaka.

3. Ali, M., \& Azmi, W. (2016). Religion in the boardroom and its impact on Islamic banks' performance. Review of Financial Economics, 31, 83-88. https://doi.org/10.1016/j.rfe.2016.08.001

4. Andrevski, G., Richard, O. C., Shaw, J. D., \& Ferrier, W. J. (2014). Racial Diversity and Firm Performance: The Mediating Role of Competitive Intensity. Journal of Management, 40(3), 820-844. https://doi.org/10.1177/ 0149206311424318

5. Darmadi, S. (2011). Board diversity and firm performance: The Indonesian evidence. Corporate Ownership and Control, 8, 524-539. https://doi.org/10.22495/cocv8i2c4p4

6. DiTomaso, N., Post, C., \& Parks-Yancy, R. (2007). Workforce Diversity and Inequality: Power, Status, and Numbers. Annual Review of Sociology, 33, 473-501. https://doi.org/10.1146/annurev.soc.33.040406.131805

7. Ely, R. J., \& Thomas, D. A. (2001). Cultural Diversity at Work: The Effects of Diversity Perspectives on Work Group Processes and Outcomes. Administrative Science Quarterly, 46(2), 229-273.

8. Gröschl, S., \& Arcot, S. (2014). Female hospitality executives and their effects on firm performance. Tourism and Hospitality Research, 14(3), 143-151. https://doi.org/10.1177/1467358414538997

9. Gupta, R. (2013). Workforce Diversity and Organizational performance. International Journal of Business and Management Invention, 2(6), 36-41.

10. Homberg, F., \& Bui, H. T. M. (2013). Top Management Team Diversity: A Systematic Review. Group \& Organization Management, 38(4), 455-479. https://doi.org/10.1177/1059601113493925

11. Jackson, S. E., Joshi, A., \& Erhardt, N. L. (2003). Recent Research on Team and Organizational Diversity: SWOT Analysis and Implications. Journal of Management, 29(6), 801-830. https://doi.org/10.1016/S01492063_03_00080-1

12. Johnston, D., \& Malina, M. A. (2008). Managing Sexual Orientation Diversity: The Impact on Firm Value. Group $\&$ Organization Management, 33(5), 602-625.

13. Jonsen, K., Maznevski, M. L., \& Schneider, S. C. (2011). Diversity and its not so diverse literature: An international perspective. International Journal of Cross Cultural Management, 11(1), 35-62. https://doi.org/ $10.1177 / 1470595811398798$

14. Joshi, A., \& Roh, H. (2009). THE ROLE OF CONTEXT IN WORK TEAM DIVERSITY RESEARCH: A META-ANALYTIC REVIEW. Academy of Management Journal, 52(3), 599-627. https://doi.org/10.5465/ amj.2009.41331491

15. Kundu, S. (2016, December 7). Age diversity and the workplace. The Independent, p. Op-Ed. Retrieved from http://www.theindependentbd.com/arcprint/details/71403/2016-12-07

16. Low, D. C. M., Roberts, H., \& Whiting, R. H. (2015). Board gender diversity and firm performance: Empirical evidence from Hong Kong, South Korea, Malaysia and Singapore. Pacific-Basin Finance Journal, 35, 381-401. https://doi.org/10.1016/j.pacfin.2015.02.008

17. McMahon, A. M. (2010). Does Workplace Diversity Matter? A Survey Of Empirical Studies On Diversity And Firm Performance, 2000-09. Journal of Diversity Management, 5(2), 37-48.

18. Ortlieb, R., \& Sieben, B. (2013). Diversity Strategies and Business Logic: Why Do Companies Employ Ethnic Minorities? Group $\&$ Organization Management, 38(4), 481-511. https://doi.org/10.1177/1059601113497094

19. Panisoara, G., \& Serban, M. (2013). Marital Status and Work-Life Balance. Procedia - Social and Behavioral Sciences, 78, 21-25. https://doi.org/10.1016/j.sbspro.2013.04.243

20. Rashid, M. (2018, April 8). Ensuring Diversity at the workplace. Dhaka Tribune.

21. Saad, L. (2008). CA Ruling on Same-Sex Marriage Bucks Majority View. Retrieved from https://news.gallup. 
com/poll/107305/ruling-samesex-marriage-bucks-majority-view.aspx

22. Stewart, G. L. (2006). A meta-analytic review of relationships between team design features and team performance. Journal of Management, 32(1), 29-54. https://doi.org/10.1177/0149206305277792

23. US Department of State. (2016). Bangladesh 2016 International Religious Freedom Report. Dhaka. Retrieved from https://www.state.gov/documents/organization/269170.pdf

24. Webber, S. S., \& Donahue, L. M. (2001). Impact of highly and less job-related diversity on work group cohesion and performance: a meta-analysis. Journal of Management, 27, 141-162. Retrieved from http://web.a.ebscohost. com/ehost/pdfviewer/pdfviewer?sid=7778b01c-09b6-457a-8954-

dc406ef6174f\%40sessionmgr4003\&vid $=0 \&$ hid $=4114$

\section{APPENDIX A}

\section{$\underline{\text { Regression Outputs }}$}

\section{Descriptive Statistics}

\begin{tabular}{lc|c|c} 
& Mean & Std. Deviation & $\mathrm{N}$ \\
\hline OPM & .2685 & .40014 & 80 \\
\hline Gender (F to M) Ratio & .2959 & .59784 & 80 \\
\hline Racial (Foreign \& Ethnic to BD) Ratio & .0068 & .02362 & 78 \\
\hline Religion (Non-muslim to Muslim) Ratio & .4464 & 1.49813 & 77 \\
\hline
\end{tabular}

\section{Correlations}

\begin{tabular}{l|l|l} 
Gender (F & Racial (Foreign \& & Religion (Non-muslim
\end{tabular} OPM to M) Ratio Ethnic to BD) Ratio to Muslim) Ratio

\begin{tabular}{|c|c|c|c|c|c|}
\hline \multirow{4}{*}{$\begin{array}{l}\text { Pearson } \\
\text { Correlation }\end{array}$} & OPM & 1.000 & 436 & -.093 & -.044 \\
\hline & Gender ( $\mathrm{F}$ to $\mathrm{M}$ ) Ratio & .436 & 1.000 & -.011 & .274 \\
\hline & $\begin{array}{l}\text { Racial (Foreign \& } \\
\text { Ethnic to BD) Ratio }\end{array}$ & -.093 & -.011 & 1.000 & .019 \\
\hline & $\begin{array}{l}\text { Religion (Non-muslim to } \\
\text { Muslim) Ratio }\end{array}$ & -.044 & .274 & .019 & 1.000 \\
\hline \multirow{4}{*}{ Sig. (1-tailed) } & OPM & . & .000 & .209 & .351 \\
\hline & Gender ( $\mathrm{F}$ to $\mathrm{M}$ ) Ratio & .000 & . & .462 & .008 \\
\hline & $\begin{array}{l}\text { Racial (Foreign \& } \\
\text { Ethnic to BD) Ratio }\end{array}$ & .209 & .462 & . & .437 \\
\hline & $\begin{array}{l}\text { Religion (Non-muslim to } \\
\text { Muslim) Ratio }\end{array}$ & .351 & .008 & .437 & . \\
\hline \multirow{4}{*}{$\mathrm{N}$} & OPM & 80 & 80 & 78 & 77 \\
\hline & Gender ( $\mathrm{F}$ to $\mathrm{M}$ ) Ratio & 80 & 80 & 78 & 77 \\
\hline & $\begin{array}{l}\text { Racial (Foreign \& } \\
\text { Ethnic to BD) Ratio }\end{array}$ & 78 & 78 & 78 & 76 \\
\hline & $\begin{array}{l}\text { Religion (Non-muslim to } \\
\text { Muslim) Ratio }\end{array}$ & 77 & 77 & 76 & 77 \\
\hline
\end{tabular}

Variables Entered/Removed ${ }^{\mathrm{a}}$

\begin{tabular}{ll|l|l} 
Model & \multicolumn{1}{c|}{ Variables Entered } & Variables Removed & Method \\
\hline 1 & Religion (Non-muslim to Muslim) & & Enter \\
& $\begin{array}{l}\text { Ratio, Racial (Foreign \& Ethnic to BD) } \\
\text { Ratio, Gender (F to M) Ratio }\end{array}$ & & \\
\hline
\end{tabular}

a. Dependent Variable: OPM

b. All requested variables entered. 


\begin{tabular}{|c|c|c|c|c|}
\hline \multicolumn{5}{|c|}{ Model Summary ${ }^{b}$} \\
\hline Model & $\mathrm{R}$ & R Square & Adjusted R Square & Std. Error of the Estimate \\
\hline 1 & $.475^{\mathrm{a}}$ & .226 & .194 & .35935 \\
\hline
\end{tabular}

\begin{tabular}{|c|c|c|c|c|c|c|}
\hline \multicolumn{7}{|c|}{ ANOVA $^{a}$} \\
\hline Model & & Sum of Squares & df & Mean Square & $\mathrm{F}$ & Sig. \\
\hline \multirow{3}{*}{1} & Regression & 2.711 & 3 & .904 & 6.999 & $.000^{\mathrm{b}}$ \\
\hline & Residual & 9.297 & 72 & .129 & & \\
\hline & Total & 12.008 & 75 & & & \\
\hline
\end{tabular}

a. Dependent Variable: OPM

b. Predictors: (Constant), Religion (Non-muslim to Muslim) Ratio, Racial (Foreign \& Ethnic to BD) Ratio, Gender (F to M) Ratio

\begin{tabular}{|c|c|c|c|c|c|c|c|c|c|c|c|c|c|}
\hline \multicolumn{14}{|c|}{ Coefficients $^{a}$} \\
\hline \multirow[b]{2}{*}{ Model } & & \multicolumn{2}{|c|}{$\begin{array}{c}\text { Unstandardized } \\
\text { Coefficients }\end{array}$} & \multirow{2}{*}{$\begin{array}{l}\text { Standardized } \\
\text { Coefficients } \\
\text { Beta }\end{array}$} & \multirow[t]{2}{*}{$\mathrm{t}$} & \multirow[t]{2}{*}{ Sig. } & \multicolumn{2}{|c|}{$\begin{array}{c}95.0 \% \text { Confidence } \\
\text { Interval for B }\end{array}$} & \multicolumn{3}{|c|}{ Correlations } & \multicolumn{2}{|c|}{ Collinearity Statistics } \\
\hline & & $\mathrm{B}$ & $\begin{array}{l}\text { Std. } \\
\text { Error }\end{array}$ & & & & $\begin{array}{l}\text { Lower } \\
\text { Bound }\end{array}$ & $\begin{array}{l}\text { Upper } \\
\text { Bound } \\
\end{array}$ & $\begin{array}{l}\text { Zero- } \\
\text { order }\end{array}$ & Partial & Part & Tolerance & VIF \\
\hline \multirow{4}{*}{1} & (Constant) & .204 & .048 & & 4.229 & .000 & .108 & .299 & & & & & \\
\hline & $\begin{array}{l}\text { Gender ( } \mathrm{F} \text { to } \mathrm{M}) \\
\text { Ratio }\end{array}$ & .323 & .072 & .483 & 4.475 & .000 & .179 & .467 & .436 & .466 & .464 & .925 & 1.081 \\
\hline & $\begin{array}{l}\text { Racial (Foreign } \\
\text { \& Ethnic to BD) } \\
\text { Ratio }\end{array}$ & -1.431 & 1.758 & -.084 & -.814 & .418 & -4.935 & 2.073 & -.093 & -.096 & -.084 & .999 & 1.001 \\
\hline & $\begin{array}{l}\text { Religion (Non- } \\
\text { muslim to } \\
\text { Muslim) Ratio }\end{array}$ & -.047 & .029 & -.175 & -1.621 & .109 & -.104 & .011 & -.044 & -.188 & -.168 & .925 & 1.082 \\
\hline
\end{tabular}

a. Dependent Variable: OPM

\begin{tabular}{|c|c|c|c|c|c|c|c|}
\hline \multirow[b]{3}{*}{ Model } & \multirow[b]{3}{*}{ Dimension } & \multicolumn{5}{|c|}{ Collinearity Diagnostics ${ }^{\mathrm{a}}$} & \\
\hline & & \multirow[b]{2}{*}{ Eigenvalue } & \multirow[b]{2}{*}{$\begin{array}{c}\text { Condition } \\
\text { Index }\end{array}$} & \multicolumn{4}{|c|}{ Variance Proportions } \\
\hline & & & & (Constant) & $\begin{array}{l}\text { Gender }(\mathrm{F} \\
\text { to } \mathrm{M}) \text { Ratio }\end{array}$ & $\begin{array}{c}\text { Racial (Foreign \& } \\
\text { Ethnic to BD) Ratio }\end{array}$ & $\begin{array}{c}\text { Religion (Non-muslim } \\
\text { to Muslim) Ratio }\end{array}$ \\
\hline \multirow{4}{*}{1} & 1 & 1.834 & 1.000 & .13 & .13 & .05 & .11 \\
\hline & 2 & .959 & 1.383 & .01 & .07 & .71 & .14 \\
\hline & 3 & .693 & 1.627 & .20 & .15 & .12 & .71 \\
\hline & 4 & .514 & 1.890 & .65 & .65 & .12 & .04 \\
\hline
\end{tabular}

a. Dependent Variable: OPM

\section{Casewise Diagnostics ${ }^{\mathrm{a}}$}

\begin{tabular}{l|c|c|c|c} 
Case Number & Std. Residual & OPM & Predicted Value & Residual \\
\hline 58 & 5.650 & 3.03 & .9957 & 2.03035 \\
\hline 61 & -3.269 & -.90 & .2768 & -1.17482 \\
\hline a. Dependent Variable: OPM
\end{tabular}


Residuals Statistics ${ }^{\mathrm{a}}$

\begin{tabular}{lc|c|c|c|c} 
& Minimum & Maximum & Mean & Std. Deviation & $\mathrm{N}$ \\
\hline Predicted Value & .0501 & 1.6679 & .2712 & .19441 & 76 \\
\hline Std. Predicted Value & -1.148 & 7.360 & .014 & 1.022 & 76 \\
\hline Standard Error of Predicted Value & .041 & .313 & .064 & .054 & 76 \\
\hline Adjusted Predicted Value & -.0421 & 4.8582 & .3051 & .53464 & 76 \\
\hline Residual & -1.17482 & 2.03035 & .00274 & .35944 & 76 \\
\hline Std. Residual & -3.269 & 5.650 & .008 & 1.000 & 76 \\
\hline Stud. Residual & -5.792 & 6.363 & -.021 & 1.210 & 76 \\
\hline Deleted Residual & -4.21738 & 2.57515 & -.03117 & .62276 & 76 \\
\hline Stud. Deleted Residual & -7.870 & 9.552 & -.009 & 1.595 & 76 \\
\hline Mahal. Distance & .006 & 55.748 & 3.045 & 9.263 & 76 \\
\hline Cook's Distance & .000 & 26.049 & .382 & 3.000 & 76 \\
\hline Centered Leverage Value & .000 & .743 & .041 & .124 & 76 \\
\hline
\end{tabular}

a. Dependent Variable: OPM

Normal P-P Plot of Regression Standardized Residual

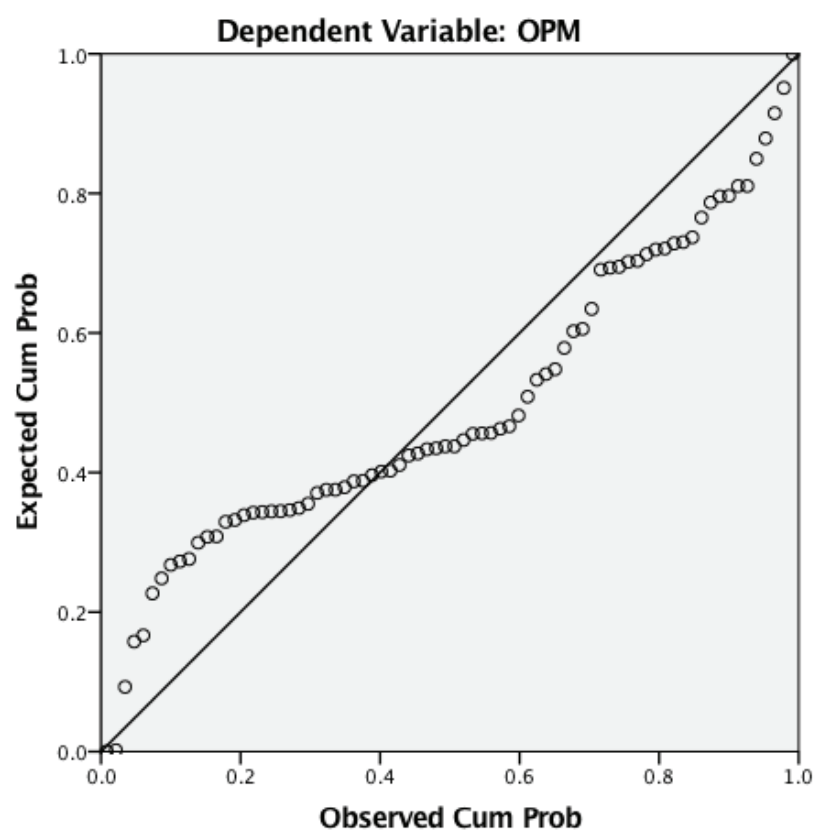




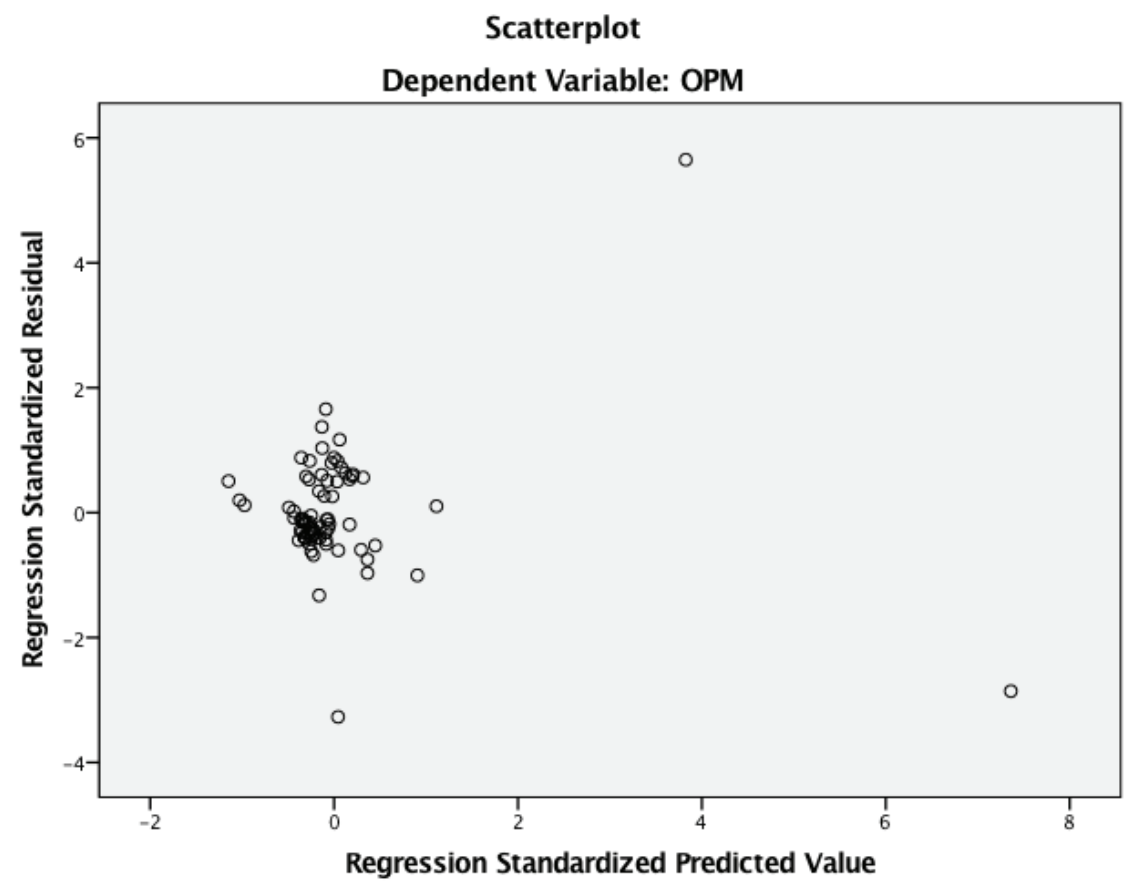

